\title{
ZA CZYM TĘSKNIMY?
}

\section{ZYGMUNT BAUMAN, RETROTOPIA}

Agata Dembek

Akademia Leona Koźmińskiego

Swoją ostatnią książkę Zygmunt Bauman poświęcił brakowi i tęsknocie. Można zastanawiać się, na ile to znaczący wybór tematyki i co mówi o czasie, w którym Retrotopia została napisana. Diagnozy o aktualnym stanie zachodniej kultury, zarówno publicystyczne, jak i te akademickie, kreśla obraz momentu przełomu, schyłku i niepewności. Jak zauważa Mark Featherstone (2017), śmierć Baumana zbiegła się w czasie z Brexitem, wyborem Donalda Trumpa na prezydenta USA i wzrostem znaczenia sił skrajnie prawicowych w Europie, a także z eskalacją wojny informacyjnej prowadzonej przy użyciu fake news. Owa zbieżność jest wymowna i trudno od niej abstrahować, czytając Retrotopie.

Recenzje Retrotopii (np. Lyon 2017, Kościelniak 2017, Polhuijs 2017) często traktuja ja jako quasi-podsumowanie dorobku Baumana i swoiste pożegnanie. Zdają się nie oceniać jej jako osobnego dzieła. Być może słusznie, książka bowiem niewątpliwe zyskuje, gdy osadzimy ją w kontekście konsekwentnego projektu krytyki kultury późnego kapitalizmu, jaki budował Zygmunt Bauman m.in. w serii swoich prac o różnych wymiarach płynnej nowoczesności. Dzięki temu zdejmuje się z Retrotopii ciężar „finalnego osiągnięcia” czy „ostatniego dzieła”, którego to ciężaru, również w mojej ocenie, książka by nie uniosła. Jednocześnie jej struktura, podział na cztery części traktujące o czterech fantazjach o powrocie (do Hobbesa, do plemion, do nierówności i do łona), faktycznie nawiązuje do tematów refleksji, które były dla Baumana ważne na przestrzeni ostatnich dekad. Nawiązując do prac Svetlany Boym (2001), autor zauważa, że nostalgia główny temat refleksji w Retrotopii - jest dla nas źródłem informacji o teraźniejszości i jej brakach. Wspomniane cztery rodzaje powrotów symbolicz- 
nie tworzą katalog cierpień współczesności. Są to te same źródła cierpień, które identyfikował Bauman w swoich wcześniejszych pracach, jest jednak bardzo krytyczny wobec retrotopijnych odpowiedzi na nie.

Autor nazywa retrotopia „wizje osadzone w utraconej/skradzionej/ porzuconej, ale nieumarłej przeszłości, zamiast przywiązania do tego, co dopiero ma się narodzić, a więc do przyszłości jeszcze nie zaistniałej" (Bauman 2017: 7, ebook), „zjawisko pochodne negacji drugiego stopnia - a więc coś, co jest negacją negacji dokonanej przez utopię. Z dziedzictwem Thomasa More'a dzieli ona niewzruszone przywiązanie do terytorialnie suwerennego toposu: stałego gruntu, który, jak można żywić nadzieję, zagwarantuje akceptowalne minimum stabilności oraz, dzięki temu właśnie, wystarczającą dawkę pewności siebie" (tamże: 10). I dalej: „Wierna duchowi utopii retrotopia wywodzi swój impuls z nadziei na ostateczne pogodzenie bezpieczeństwa $\mathbf{z}$ wolnością: wyczyn, na który i wizja oryginalna, i pierwsza jej negacja nie próbowały się zdobyć, a nawet jeśli, kończyło się to porażką" (tamże: 11) (podkr. A.D.). Kilka elementów przywołanych opisów wymaga komentarza.

Po pierwsze, nie ma tu mowy o przeszłości, ale o fantazji na jej temat. Co istotne, w wizji tej wspaniała przeszłość została utracona lub odebrana, przez co zostaje nasycona elementami straty i krzywdy. Po drugie, obiecuje ona stabilność, pewność i przynależność. Stanowi więc negatyw kondycji kultury późnego kapitalizmu, charakteryzującej się „płynnością, zmiennością i różnorodnością. Po trzecie wreszcie, będąc fantazją właśnie, której nie obowiązuje zasada rzeczywistości, retrotopia oferuje bezpieczeństwo, zachowując jednocześnie silne deklaratywne odniesienie do kluczowej wartości liberalnej demokracji - a szerzej: projektu nowoczesnego - czyli wolności. Szybko jednak okazuje się, że przy próbie opisu retrotopijnej fantazji wolność okazuje się pustym pojęciem ${ }^{1}$.

Społeczeństwo jednostek wymusza grę o sumie zerowej (tamże: 99). Brak zakorzenienia w realności oraz brak zaspokojenia realnych potrzeb materialnych i emocjonalnych w świecie prowadzi do wzmożonego fan-

\footnotetext{
${ }^{1}$ Ciekawym satyrycznym eksperymentem, który może tę zależność ilustrować, była „sonda” przeprowadzona w 2016 roku przez „korespondentów” programu The Daily Show with Trevor Noah wśród zwolenników - wówczas - kandydata Partii Republikańskiej na prezydenta, Donalda Trumpa. Odnosząc się do sloganu „Make America Great Again”, pytali oni, kiedy Ameryka była wielka (When was America great?) - czyli do jakiej przeszłości wyborcy pragną wrócić. Wśród odpowiedzi można było usłyszeć, że chodzi o moment podpisania deklaracji niepodległości, o okres powojenny (lata 40.-50. XX w.), o okres przed Wielkim Kryzysem lat 30. Oczywiście, w okresach tych w USA obowiązywało niewolnictwo (w pierwszym przypadku), segregacja rasowa, czy pozbawienie kobiet praw wyborczych (w kolejnych przypadkach). https://www.youtube.com/watch?v=uVQvWwHM5kM; dostęp:11.09.2018.
} 
tazjowania, nostalgii za nieistniejąca przeszłością i życia fantomowego. „Chroniczny brak usług zaspokajających autentyczne potrzeby staje się znośny dzięki strategii iluzorycznego zaspokajania potrzeb fantomowych" (tamże: 120). Sytuacja ta jest źródłem bólu, fantomowego w dwójnasób, bo odnosi się do utraty tego, czego nigdy faktycznie nie było. Jednak trafność użytego przez Baumana określenia wynika z tego, że bóle fantomowe odczuwane sa jako realne, przez co mają realne konsekwencje. Jedną z tych konsekwencji jest gniew, będący pożywką dla przemocy (tamże: 37). Mając w pamięci argumentację Rollo Maya (1978), który opisywał przemoc jako próbę przełamania charakterystycznego dla późnej nowoczesności doświadczenia apatii i wygenerowania poczucia kontaktu ze światem, wydaje się zasadne spojrzenie na retrotopijne fantazje w podobny sposób. Nostalgia za przeszłością, której nigdy nie było, ma dać odpór chronicznemu poczuciu niemocy i braku nadziei.

$[\mathrm{P}]$ roblem z płynnym społeczeństwem nie polega tylko na tym, że jest ono trudne do zrozumienia, ale także na tym, że jest prowizoryczne, tymczasowe, samotne, pozbawione miłości, głupie, bezkrytyczne, i nieetyczne, ponieważ brakuje trwałych relacji społecznych, umożliwiających przetrwanie w dobrych czasach, lub, co ważniejsze, w złych czasach, kiedy potrzebujemy wsparcia i troski o siebie nawzajem (Featherstone 2017: 286).

Poczucie, że w świecie, który jest, nic nie możemy i na nic nie mamy realnego wpływu, współwystępujące z nieprzerwaną promocją autonomii, samorealizacji i biografii projektu - to, zdaniem Baumana, cierpienie cechujące opisanego przez Christophera Lascha współczesnego narcyza.

Pośród fundamentalnych pytań jest kwestia tego, czy tendencje narcystyczne należy postrzegać i traktować jako „zaburzenia osobowości” [...], czy może jako „zaburzenia spoteczeństwa”. Czy sa to raczej powielane, lecz wciąż marginalne aberracje indywidualne (i mamy nadzieję, że takimi będą musiały pozostać) - czy też symptomy kształtującej się nowej normy? (Bauman 2017:. 123, podkr. Z.B.).

Wyobraźnia socjologiczna Baumana kieruje go oczywiście ku drugiej odpowiedzi. Być może warto dodatkowo wesprzeć tę diagnozę analizą zaproponowana przez historyka. 
Timothy Snyder (2018) w swojej najnowszej pracy opisuje zmianę, jaka następuje w ostatnich latach w społecznym wyobrażeniu czasu i historii w kulturze euroatlantyckiej. Chodzi o przejście od wizji, którą nazywa polityka nieuchronności (the politics of inevitability), do polityki wieczności (the politics of eternity). Ta pierwsza, dominująca na Zachodzie pod koniec $\mathrm{XX}$ w. i na przełomie wieków, cechuje się wiarą w określony kierunek rozwoju społeczeństw - ku liberalnej demokracji, gospodarce rynkowej, integracji gospodarczej, dobrobytowi, słowem: ku końcowi historii. Natomiast polityka wieczności, której popularność Snyder wywodzi z ideologicznej ekspansji Rosji Putina oraz z kryzysów politycznych i ekonomicznych, których doświadczamy w ostatnich dwudziestu latach, każe widzieć historię jako cykliczny proces powtarzających się zagrożeń i krzywd dotykających wspólnotę, rozumianą jako naród. Co szczególnie ciekawe w kontekście rozważań nad Retrotopią, obie wyróżnione wizje historii wywołują poczucie niemocy i zniechęcają do podejmowania prób interwencji w rzeczywistość i jej zmiany. Polityka nieuchronności oznacza brak alternatywy (TINA). Z kolei polityka wieczności kreuje wizję niemożliwych do uniknięcia nieszczęść i zagrożeń, które ze swej natury odbierają wiarę w możliwość odmiany losu. Bauman zauważa: „Coś, co wciąż zwykliśmy nazywać «postępem», wywołuje emocje przeciwne do tych, które Immanuel Kant, twórca tego pojęcia, miał na myśli. Coraz częściej zatem wywołuje ono strach przed nieuchronną katastrofą zamiast wywoływać radość, że oto nadchodzi większy dobrobyt [...]" (Bauman 2017: 58).

Snyder przekonuje, że obie „polityki” to potężne iluzje, zdolne do zastapienia faktów narracjami. W konsekwencji, szczególnie w drugim przypadku, poczucie bezradności i niemocy stanowi skuteczną pożywkę dla gniewu, chęci odwetu, nacjonalizmu i ksenofobii. Stan ten Bauman nazywa powrotem do Hobbesa i powrotem do plemion. Retrotopia to książka o tym, jak w obliczu klęski utopii projektu rośnie w siłę fantazja rewanżu i zaprzeczenia ${ }^{2}$. Zmiana w sposobie wyobrażenia i doświadczania historii, podobnie jak to, co czynimy przedmiotem nostalgicznych tęsknot (szczególnie charakterystycznych dla nostalgii krzepiącej - restorative, Boym 2001), jest więc informacja o dynamice teraźniejszości.

Społeczna gra o sumie zerowej (Bauman 2017: 99) oraz utrata pozytywnej wiary w postęp skutkuja, a zapewne w pewnym stopniu wynikaja z podważenia podstaw zaufania - do siebie nawzajem, ale i do społecznie podzielanej wizji świata, rozumienia prawdy i fałszu. Przyjmijmy, że gdy nikomu i niczemu już się nie ufa, nie sposób fantazjować o przyszłości,

\footnotetext{
2 Por. także analizę utopii retrospektywnej w tekście Dariusza Brzezińskiego w niniejszym tomie.
} 
a gdy wszystkie obietnice okazują się fałszywe, w ogóle trudno ją sobie wyobrazić. Można jednak fantazjować o przeszłości, która - jak się wydaje - jest znana i może stanowić stabilny punkt odniesienia. Wymiar faktograficzny okazuje się tutaj w najlepszym wypadku drugorzędny, jeśli nie zupełnie nieistotny. „Prawda nie jest prawdą”. Rozpad względnie wspólnego obrazu świata społecznego oczywiście pogłębia atomizację, już nie tylko na poziomie doświadczeń i emocji, ale także moralności.

Nowa moralność zmieniła swój wektor z odśrodkowego na dośrodkowy: niegdyś w roli nadrzędnego środka spajającego w budowaniu mostów w ramach relacji interpersonalnych, skracaniu dystansu i integracji, dziś dołącza ona do znacznego i wciąż rosnącego przybornika rozłamu, podziału, przemieszczenia, alienacji i rozdarcia (tamże: 128).

Zauważmy subtelną ewolucję tonu, jakim Bauman opowiada o tych zmianach. O ile jeszcze na początku wieku, np. w Raz̧em, osobno (2003), z niepokojem i smutkiem diagnozował ,upadek sztuki socjalności”, o tyle w swojej ostatniej książce pisze już o całkowitym rozpadzie tkanki społecznej i podstawowych instytucji. Zmiana wektora moralności utrudnia, jeśli nie pozbawia nas zdolności odwołania się do przekładalności perspektyw, którą Thomas Luckmann (2006) postrzegał jako „uniwersalne ludzkie źródło moralności” i „cechę konstytutywną” intersubiektywności. W konsekwencji, „[w] pewnym sensie, moralność definiuje się jako problem, a nie jako rozwiązanie" (Luckmann 2006: 945). Z kolei Alain Touraine (2013) twierdzi, że mamy obecnie do czynienia z „sytuacja postspołeczną", całkowitym rozdzieleniem ekonomii i moralności. Jego zdaniem właściwą odpowiedzią powinien być zwrot ku podmiotowi moralnemu, ujmowanemu jednak poza kontekstem powiązań, ról i zobowiązań społecznych. Wobec tej przesyconej samotnością propozycji retrotopijna nostalgia za doświadczeniem silnych więzi wspólnotowych (plemienność) oraz za powrotem do łona (fantazmat relacji symbiotycznej) jawi się jako niemal nieuchronna.

Pisząc o fantazji powrotu do łona, Bauman pisze o nirwanie (2017: 143). Z barwnego, literackiego opisu przebija rozpaczliwe wołanie współczesnej jednostki o odpoczynek. Powrót do łona ma symbolizować od-

\footnotetext{
${ }^{3}$ „The truth isn't truth” - powiedzial na antenie telewizji NBC 19.08.2018 r. prawnik Donalda Trumpa i były burmistrz Nowego Jorku, Rudy Giuliani. „Lapsus” ten, powtórzony kilkakrotnie, dość powszechnie został uznany przez komentatorów za symptomatyczny dla obecnej kondycji debaty publicznej w USA (a także za godnego następcę „faktów alternatywnych”). Wydaje się, że może on także ilustrować skalę rozbieżności we współczesnej polskiej debacie.
} 
puszczenie i bezpieczeństwo. Sekwencja rozdziałów w książce wydaje mi się nieprzypadkowa. Marzenie o nirwanie staje się bardziej zrozumiałe po zapoznaniu się z udręką fantazji o pozostałych powrotach. Fantazja ta, inaczej niż np. powrót do plemienności, wybrzmiewa jako uniwersalne ludzkie pragnienie, nieoparte na podziałach „my - oni”, w równym stopniu właściwe wszystkim. Choć Bauman nie pisze o tym wprost, można z toku jego narracji wnioskować, że kolejne fantazje o powrotach wzajemnie się wzmacniaja, tworzac spiralę pogłębiającego się - do pewnego stopnia paradoksalnie - wyobcowania i osamotnienia.

Autor rozpoczyna Retrotopie od przywołania słynnego opisu Waltera Benjamina ze szkicu O pojeciu bistorii (2012: 316) nt. obrazu Angelus Novus Paula Klee. Zauważa jednak, że współcześnie anioł zwrócony byłby w przeciwnym kierunku - twarzą ku przyszłości, ,ze skrzydłami odgiętymi w tył pod naporem wichru wiejącego tym razem od piekła przyszłości [...] w stronę przeszłości i jej raju" (tamże: 4). Kłopot z tym opisem polega na tym, że anioł ów podążać musi ku przyszłości tak czy inaczej, a fantazje o „raju utraconym i popadłym w ruinę” tej wędrówki nie spowolnią. Lektura Retrotopii nie pozostawia czytelnikowi w tej sprawie watpliwości. Tym bardziej znaczące są rozważania zawarte w epilogu, gdzie Bauman przywołuje obszerne fragmenty przemówienia Papieża Franciszka z 2016 roku. Mowa w nim o tym, że jedynym i koniecznym wysiłkiem, jaki musimy podjać, by - dosłownie - uratować życie na Ziemi, jest wychowanie naszych dzieci do dialogu i nieustanne próby poszukiwania porozumienia mimo różnic i podziałów. „Bardziej niż kiedykolwiek - pisze Bauman jesteśmy postawieni - my, ludzie, mieszkańcy Ziemi - w sytuacji albo-albo: albo wkroczymy we wspólną przyszłość, albo skończymy w zbiorowej mogile" (tamże: 163). Konkluzja ta, której trudno odmówić trafności, do pewnego stopnia jednak rozczarowuje. Habermasowska w duchu recepta łącząca dialog i troskę o dobro wspólne zdaje się niemal ignorować wywiedzione we wcześniejszych rozdziałach diagnozy radykalnego rozbicia wspólnego porządku wartości, nasilenia fantazji o podziałach plemiennych i eskapistycznych marzeń o powrocie do łona. W tych warunkach apele o dialog wydają się brzmieć archaicznie i nierealistycznie. Lektura Retrotopii wywołuje wrażenie, że nie ma już miejsca na rozmowę, nie ma wspólnego mianownika. I choć niewątpliwie, z historycznej perspektywy, ludzie byli zdolni do podjęcia dialogu w sytuacji bardziej radykalnych podziałów, dziś - jak się zdaje - trudno jest nam sięgnąć do tych doświadczeń. Jednocześnie jednak odwołanie do słów Papieża Franciszka o podstawowej potrzebie poszukiwania porozumienia przywołuje skojarzenia z refleksjami 
Leszka Kołakowskiego o przyjaźni, publikowanymi w polskiej prasie pod koniec życia filozofa. Chodzi mianowicie o powrót do kwestii podstawowych - ale nie powrót w czasie czy powrót rewanżystyczny, ale o sięgnięcie do wartości i treści, które czynią możliwym zrozumienie siebie nawzajem. Czyli do tego, co mimo wszystko jest nam wspólne.

Bibliografia

/// Bauman Z. 2003. Razem, osobno, tłum. T. Kunz, Wydawnictwo Literackie.

/// Bauman Z. 2017. Retrotopia, Polity Press.

/// Benjamin W. 2012. O pojeciu historii, [w:] Konstelacje: wybór tekstów, tłum. A. Lipszyc, A. Wołkiewicz, Wydawnictwo Uniwersytetu Jagiellońskiego.

/// Boym S. 2001. The Future of Nostalgia, Basic Books.

/// Featherstone M. 2017. After Bauman, „Cultural Politics”, 13(3), s. 284 287.

/// Kościelniak C. 2017. Czytanie Baumana dzis', „Kultura Liberalna”, 425(9).

/// Luckmann T. 2006. Komunikacja moralna we wspótczesnych społeczeństwach, tłum M. Marody, [w:] Wspótcz̨esne teorie socjologiczne, t. 2, red. A. Jasińska-Kania, L.M. Nijakowski, J. Szacki, M. Ziółkowski, Wydawnictwo Naukowe Scholar, s. 938-947.

/// Lyon D. 2017. Bauman's Sociology of Hope, „Cultural Politics', 13(3), s. 296299.

/// May R. 1978. Mitosí i wola, tłum. H. i P. Śpiewakowie, Państwowy Instytut Wydawniczy.

/// Polhuijs Z. 2017. Review of Zygmunt Bauman, Retrotopia, „Theory, Culture \& Society". https://www.theoryculturesociety.org/review-zygmunt-bauman-retrotopia/; dostęp: 11.09.2018.

/// Snyder T. 2018. The Road to Unfreedom: Russia, Europe, America, Tim Duggan Books.

/// Touraine A. 2013. Po kryzysie, tłum. M. Frybes, Oficyna Naukowa. 
/// Agata Dembek - socjolożka, adiunkt w Katedrze Zarządzania w Społeczeństwie Sieciowym w Akademii Leona Koźmińskiego. Aktualnie Visiting Scholar w Institute for Public Knowledge, New York University (2018-2019). Jej zainteresowania badawcze obejmują etnografię organizacji, problematykę zrównoważonego rozwoju i przedsiębiorczości zrównoważonej oraz metodologię badań jakościowych.

Email: adembek@kozminski.edu.pl 